\title{
MANAGING GROWTH OF MICROFINANCE INSTITUTIONS (MFIS): BALANCING SUSTAINABILITY AND REACHING LARGE NUMBER OF CLIENTS IN ETHIOPIA ${ }^{1}$
}

\author{
By Wolday Amha
}

\begin{abstract}
The overriding objective of MFIs in Ethiopia is to provide a broad range of microfinance services to large numbers of poor households. This is realized by developing capable and sustainable MFIs. A large number of MFIs have achieved significant progress in terms of both outreach and sustainability. As of June 2005, the twenty six deposit taking MFIs had an active loan portfolio of about 1.5 billion Birr (173 million USD) delivered to 1,211,305 active clients. They mobilized about 501million Birr (58 million US dollars) in savings. The Ethiopian MFIs attained such a significant outreach in a brief period of time. Between 2001 and 2005 , the number of clients, volume of loan portfolio and savings increased by $263 \%$, $479 \%$, and 206\%, respectively. In 2004, 12 out of the 15 MFIs were operationally sustainable, while 5 were financially sustainable. The majority of the MFIs increased their efficiency and productivity indicators as a result of expansion or increase in outreach. Out of the $15 \mathrm{MFIs}$, eleven had less than 5\% portfolio at risk, which was encouraging. Out of the 13 MFIs which registered significant growth in outreach, 9 showed a remarkable decline in their portfolio at risk. As a result of the increased outreach, many of the MFIs maintained and some improved their portfolio quality.
\end{abstract}

A careful balancing of increasing outreach and sustainability; with a parallel focus on institutional capacity; reducing costs and risks; and improving efficiency, profitability and portfolio quality, is needed to address the financial demand millions of unbanked people in Ethiopia. The specific interventions to increase the growth and sustainability of MFIs include: (a) Improving the institutional capacity of the MFIs by the implementing an efficient organizational structure, (changes in organization culture, structure and systems, for instance, decentralized lending decisions) with appropriate staff incentive and reward system, improvement of the skill of human resource, good governance, introduction of innovative financial products, and the increase of geographic expansion; (b) creating an enabling legal, regulatory and policy environment; (c) improve access to capital; (d) selective government and donor support; and (e) improving the demand side of the equation.

\footnotetext{
${ }^{1}$ The final version of this article was submitted in November 2006

2 Director of the Association of Ethiopian Microfinance Institutions (AEMFI)

** I would like to thank Mr. Tsegaye Anebo (Financial Analyst of the Association of Ethiopian Microfinance Institutions) and Dr. Tekie Alemu (Economics Department, AAU) for their professional input
} 


\section{Introduction}

\subsection{Background}

Poverty in Ethiopia is a manifestation of complex factors such as high population growth, environmental degradation, high unemployment, drought, low level of literacy, limited access to resources, health and education services, etc. Since poverty in Ethiopia is a national crisis caused by multi-dimensional problems involving multiplicity of actors, there is no single guaranteed approach to its eradication. The solutions to poverty are as multifaceted as its causes.

Addressing poverty has been the subject of many development programs in Ethiopia. Delivering financial services to poor households, by increasing employment, income, consumption and empowerment of disadvantaged groups, has been viewed as one of the antipoverty tools of development programs. Improving financial access to the poor also facilitates economic growth by easing liquidity constraints, and providing capital to startup new production related activities or adopt new technologies.

Yet, microfinance is not a panacea for poverty and related development challenges. Microfinance alone cannot improve roads, housing, water supply, education, and health services. However, it can play an important role in making the above interventions be more fruitful. It is a means to empower and build the confidence and self-esteem of the poor and the disadvantaged groups.

In order to provide microfinance services to poor households through sustainable microfinance institutions (MFIs), the government of Ethiopia issued its first microfinance legislation in 1996. The main objective of the microfinance institutions is the delivery of micro-loans, micro-savings, micro-insurance, money transfer, etc to large number of productive but resource-poor people in rural and urban areas, including micro and small entrepreneurs in a cost-effective and sustainable way. At the end of the day, the interventions of MFIs should contribute to positive and measurable impacts on the wellbeing of millions of households in Ethiopia. Thus, increasing the outreach in the delivery of financial services is very critical for Ethiopian MFIs in their effort of reducing poverty, ensuring food security and contributing to economic growth.

Delivering microfinance services to large number of households would not be sustainable unless the microfinance institutions adhere to sustainability, efficiency and productivity objectives. Although the Ethiopian MFIs have increased their outreach, efficiency, sustainability and improved portfolio quality in a short span of time, the relationship between the growth in outreach and performance indicators of 
MFIs need to be properly studied. To the knowledge of the author, there are hardly such studies which examined the above relationships. The objective of this study is to fill the gap in research and study the relationship and factors that affect growth of outreach and performance variables in the Ethiopian MFIs.

\subsection{Objectives}

The objectives of the study are to:

1) Assess the performance of the MFIs in Ethiopia in terms of the growth of outreach;

2) Study the relationship between growth of outreach of MFIs and the performance indicators (financial, efficiency, and productivity) indicators

3) Examine the factors that affect growth of MFIs; and

4) Identify the interventions required to manage growth of outreach.

\subsection{Research questions}

This study attempts to respond to the following key questions which MFIs in Ethiopia are confronted with in their effort of increasing outreach, efficiency, productivity, and improve portfolio quality. These include: (i) What are the challenges of rapid expansion of MFIs in Ethiopia? (ii) Is rapid growth an illusion, unsustainable and costly to MFIs? (iii) Do MFIs need expansion? (iv) What are the factors that determine growth of MFIs? ( $v$ ) What is the relationship between growth, productivity, sustainability, efficiency and portfolio quality? And (vi) How do MFIs manage growth?

\subsection{Data}

The data set for this study is collected from the Performance Monitoring Unit of the Association of Ethiopian Microfinance Institutions (AEMFI); and secondary information collected from various research reports and surveys.

\subsection{Organization of the paper}

The paper is organized in six sections. Section two describes the conceptual framework. Section three reviews the development of the microfinance industry in Ethiopia. Section four analyses the relationship between growth of outreach and financial viability, efficiency and portfolio quality indicators. Section five presents factors affecting the growth of outreach of MFIs. Section six concludes by summarizing the main findings of the study, policy implications and recommendations. 


\section{Conceptual framework}

Finance is one of the key elements in addressing development issues. It is even considered to play a leading role in guiding development interventions. Whatever development strategies or programs (poverty reduction strategy, rural development strategy, industrial development strategy, food security strategy, etc.,), we may propose for Ethiopia, there will always be a need for finance and financial systems to implement them.

The provision of finance contains two basic elements: (i) capital, the funds which are being provided; and (ii) financial system, the process of providing them and the institutions involved in this process (Krahnen and Schmidt, 1994). If the objective is to deliver financial services to rural and urban households, we need to have both the capital, and well-functioning financial systems and institutions. In order to increase outreach, efficiency and sustainability, $\mathrm{MFIs}^{3}$ require interventions at the level of the whole economy (such as the structural adjustment program), at the level of the financial sector (such as the financial sector reform), and interventions focused on individual financial institutions or, as the case may be, on their customers (Krahnen and Schmidt, 1994).

In the Ethiopian context, at least in the short-run, there are banks with excess liquidity. Currently, even if the minimum saving interest rate declined from $6 \%$ to $3 \%$ in the last three years, the saving deposits of banks increased significantly. To convert these savings into investment, we need sustainable and capable financial institutions that can mobilize savings and at the same time provide loans to urban and rural households.

\subsection{Historical development of finance and development}

The objective of this section is to review the development of finance and development, with particular emphasis on the delivery of financial services to the unbanked. The review of the historical development of finance and development will provide useful information on how to increase growth of outreach using sustainable financial systems and institutions. Starting with theoretical concept might be irrelevant for practitioners. However, we must recognize that theory has shaped policies to a much larger extent in this field than in many other fields of development. According to Krahnen and Schmidt (1994), there are four views on the role of finance for development.

\footnotetext{
${ }^{3}$ Financial institutions, in the broader sense include all actual providers of financial services and the interactions with their customers.
} 


\section{(i) Traditional approach (50s-60s)}

According to the traditional approach, investment is a necessary prerequisite for growth that requires the availability of capital. The role of finance is explained as part of growth theory and capital. Finance is the determinant of growth. Moreover, underdevelopment is the result of a vicious circle of poverty, i.e., poor people are poor because their income is so low that they cannot save, and thus can not invest. No doubt that investment is important for growth (which could be generated through local or foreign saving mobilization), the issue lies on the mechanism of transforming savings into investment (collecting and allocating savings). However, local income, saving and investment is low, thus foreign savings have to augment local savings and close the "saving gap". The real-asset transfers to the developing countries will bring positive linkage effects. Underlying this approach was the notion that a policy of targeted investment in large-scale industry and infrastructure would in the final analysis lead to a broad-based and socially balanced process of economic development: "trickle-down" was the phrase that summed up the essence of this policy, which included the provision of loans at low interest rates with long maturities as a core element. This has been a complete failure. Contrary to the expectations of the time, the injection of external capital had exacerbated the existing social and economic inequalities and led to widespread poverty instead of socially balanced growth (Schmidt and Zeitinger, 1996).

\section{(ii) Target-group-oriented approach (era of specialized development banks) (60s-80s)}

In the 70s, the growth theory (trickle down approach), particularly the impact of the infusion of capital into big development projects on increasing income of poor households were questioned. There was a change towards worldwide social policy aiming at income generation, poverty alleviation, employment creation and similar objectives. The new approach focused on specific target groups such as commercial farmers, smallholder farmers, small entrepreneurs, etc. The basic understanding of finance remained the same as before, only the recipients changed (farmers and small businesses instead of big business and public institutions). Finance was viewed as just providing credit and the financial system did not matter for development. However, this approach provided better attention to finance in the sense of financial systems development. Development planners were looking for methods of distributing credit to poor farmers, small businesses, etc. This led to the development of institutions such as specialized development banks in Africa, Asia and Latin America. However, development banks proved to be costly (needed huge subsidy), unprofitable, inefficient and failed to reach the target groups. There were also attempts to identify new institutions such as 
NGOs and cooperatives which started using new methods as group financing, but the experiments were only a drop in the bucket.

\section{(iii) Financial systems development (70s-80s)}

The approach advocates that the financial systems of developing countries is misused and repressed (policy of financial repression) which need to be liberalized and strengthened. It focused on financial intermediation which is the essence of a financial system. The three main propositions of the advocates of this approach included:

(a) The quantity and quality of financial intermediation that is available in a given society is a very important determinant of development,

(b) The quantity and quality of financial intermediation is determined nearly exclusively by the economic policies pursued by respective governments and

(c)The best policy is a policy of drastic deregulation of financial system.

\section{(iv) Finance, institutions and incentives (80s-90s)}

This approach holds that economic development depends more on the availability of efficient institutions than on anything else, and the most important institutional prerequisite is the existence of sustainable and capable financial sector. Although the third approach rightly stressed on the importance of the financial markets, a financial system which is not repressed would not, by itself, function optimally. This particular approach focused on information and incentive problems in the development of financial sector (Stigiltz 1989).

\subsection{Paradigm shift in the delivery of financial services to the poor}

In the last 20 years, there is a growing worldwide understanding on how microfinance institutions could deliver financial services to large number of households in a sustainable way. As indicated earlier, there had been an emphasis on rural credit schemes through government projects, development banks, cooperatives and NGOs, aimed at promoting agricultural production and increasing incomes among smallholder farmers. Such schemes were characterized by over emphasis on outreach and heavily subsidized lending interest rates. Saving products for the poor and sustainability of the institutions were entirely ignored. The results of these interventions were very poor repayment rates and frequently low impact. Ironically the 
subsidy element was often highly attractive to the non-poor and more powerful and sometimes the original target groups were excluded.

The 'microfinance revolution' which emerged in the 1990s resulted in a significant paradigm shift focusing on the provision of financial services (loans, savings, insurance, money transfer, etc) on a sustainable basis. Contrary to the earlier assumption, there has been a growing awareness that the poor do not need subsidized credit. Rather what is required is sustained access to financial services. The origin of this change in paradigm can be traced to both the disillusionment with the subsidized rural credit model and a better understanding of the informal sector activities through which many of the rural and urban poor across developing countries derive their incomes. With low transaction costs, the marginal rates of return on capital in the informal finance are found to be extremely high. This implied that the major problem of poor households has been mainly availability of flexible financial services on a sustainable manner.

Under the new paradigm, microfinance is based on creating sustainable institutions using innovative methodologies and systems which can deliver financial services efficiently, including the recovery of loans at low cost. It is through the creation of such institutions that the financial frontier can be pushed forward - reaching very large number of the poor beyond the frontier of the formal financial system. Notable success in creating sustainable microfinance institutions around the world has convincingly demonstrated the viability of expanding the frontier.

Microfinance institutions consist of agents and organizations that engage in relatively small financial transactions using specialized, character-based methodologies to serve low-income households, micro enterprises, small farmers, and others who lack access to the banking system. Microfinance services may be delivered through informal, semi-formal (that is, legally registered but not under central bank regulation), or formal financial intermediaries. However, there is a need to incorporate microfinance activities into countries' financial development strategies and financial system to expand the scope and raise the efficiency of financial intermediation, either directly intermediating by mobilizing deposits or on-lending or raising finance on a wholesale basis through financial markets. The intention is to ensure that access to financial services by rural households, micro entrepreneurs, women and disadvantaged groups improves sustainability over time. 


\section{Review of the development of microfinance services in Ethiopia}

The potential demand for micro-credit in Ethiopia is enormous. For example, if we assume that there are 15 million households in Ethiopia, targeting one person per household who require micro-credit and also assuming half of the households are able poor, then over 7.5 million active clients will require micro-credit. However, there is very limited supply of financial services to the poor households. The major sources of loans or financial services in Ethiopia are as follows:

i) Commercial banks;

ii) Microfinance institutions (MFIs);

iii) Cooperatives (savings and credit cooperatives and multipurpose cooperatives);

iv) NGOs which are involved in the delivery of financial services;

v) Government projects and programs involved in providing loans;

vi) Semi-formal finance (Iqqub, Iddir, Mahiber, etc.); and

vii) Informal finance (money lenders, traders, suppliers credit, friends, relatives, etc)

The capacity of the conventional banking sector in Ethiopia has been too weak to serve the needs of the poor. The Commercial Bank of Ethiopia (CBE), Development Bank of Ethiopia (DBE) and Construction and Business Bank have only 174, 32 and 26 branches in the whole country, respectively. As of June 2005, the private banks together, had 162 branches. The newly established Cooperative Bank of Oromia had 5 branches. Most of the branches of the commercial banks are concentrated in urban areas. Many of the Woredas in Ethiopia do not have such services. For example, only $25 \%$ of the Woredas (districts) in the Amhara Region have branch banks. Even if there are banks in these Woredas, due to high collateral requirements (land or physical assets), the poor have limited access to conventional banks.

Currently, with the exception of the indirect interventions in fertilizer and improved seed credit, conventional banks in Ethiopia consider the poor as credit risks and unbankable. According to the discussions with the commercial banks in Ethiopia, a loan size below 100,000 Birr is not attractive and profitable. Thus, MFIs and savings and credit cooperatives should be designed to respond to the failure of the commercial and development banks to serve the financial needs of small farmers and MSE operators. The delivering financial services to the poor requires financial systems that reach the poor and an innovative targeting methodology and a credit delivery mechanism that helps identify and attract only the poor who can initiate and sustain productive use of loans. 
The poor in Ethiopia have low income that leads to low investment, which in turn leads to low productivity and income. Access to institutional credit that contributes to an increase in investment is very limited in the country. The majority of the poor get access to financial services through informal channels such as moneylenders, lqqub, Iddir, friends, relatives, traders, etc. (Bezabih, et al 2005). The share of informal finance in terms of borrowers and loan size is estimated to reach 69 percent and 61 percent. respectively. Among the borrowers from the informal sources, 35 percent borrowed from friends and relatives, 48 percent from private lenders, 15 percent form Iddir and two percent from lqqub. Only 3 percent of them borrowed from both relatives and other informal sources. Moreover, 10 percent of the borrowers borrowed from multiple informal financial sources. The informal lenders are able to enforce loan contracts, have high loan recovery rates and flexible loan terms. However, the interest rates are very high and the government, through the support of cooperatives and MFIs, is making efforts to curb their roles.

The semi-formal lending institutions such as lqqub (Rotating Savings and Credit Associations), Iddir, Mahber, etc are the dominant and sustainable traditional institutions that meet the financial and social needs of the poor. Iqqub which is popular both in urban and rural areas is the dominant form of savings and credit associations in Ethiopia. It is not a permanent club; it could be continued or dissolved after its members have each a turn. A member can attend lqqub meeting weekly, or bi-weekly, or monthly to collect fixed sum of payments.

The other major financial services' outlet is the savings and credit cooperatives and multi-purpose cooperatives. According to the information of the Federal Cooperative Commission, by the end of June 2004, there were 2,146 savings and credit cooperatives (1,854 urban and 292 rural) with 155,120 members, 8,233,002 Birr of equity/share capital and mobilized 496,101,082 Birr of savings. They have a total asset of 530,587,219 Birr and an outstanding loan of 7,352,782 Birr. Although there was a continuous increase in the number of savings and credit cooperatives and members, rural areas are relatively excluded. About $86 \%$ of the savings and credit cooperative members were employees with fixed monthly salary and urban-based. Moreover, about $29 \%$ of the registered savings and credit cooperative members in the country were situated in Addis Ababa.

NGO and donor funded projects in Ethiopia have been delivering relief and development services such as emergency food, health, education, water, etc since the 1970s. In terms of the delivery of financial services to the poor, NGOs were directly funding micro-credit activities as part and parcel of their poverty alleviation programs. As the delivery of microfinance activities grew, the question of operational and financial sustainability has been raised. Initially the NGOs in the country had 
positive impact in developing flexible methodologies that fit the needs of beneficiaries and tested various innovative ideas in their development programs. However, the NGO initiated micro-credit programs, before the issuance of the microfinance legislation, faced several problems of mixing social and financial objectives.

The ACDI/CEE study (1995) revealed that financial schemes of NGOs and institutions that do not follow sound and sustainable financial principles might cause more harm than good because they do not encourage financially responsible behavior. The micro-credit initiatives before the issuance of the microfinance legislation (pre 1996) had the following features:

a) The entire orientations of the micro-credit initiatives or activities in Ethiopia (pre 1996) were geared towards a project concept. The NGOs involved in micro-credit programs and government projects were not interested in establishing sustainable financial institutions that deliver diversified financial services to the poor.

b) Subsidized NGOs' micro-credit programs in Ethiopia (pre 1996), with subsidized lending interest rates, and created a problem in building sustainable financial institutions. The real interest rates (the actual interest rates deflated by the annual rate of inflation) in these programs were negative. As a result, the loans were gifts instead of loans that should be strictly repaid regularly. The microcredit programs were not able to cover their operational costs and required permanent and heavy subsidy.

c) The very high default rates faced commercial banks, NGOs and government projects were mainly the result of borrowers seeing the lending organizations as donor or government funded projects that provided financial services for a fixed period of time for humanitarian reasons.

d) The lending institutions and employees were not seriously committed and did not enforce financial discipline, provided donor funds kept on flowing.

e) The micro-credit programs focused entirely on the provision of loans to beneficiaries. Saving products were forgotten in the delivery of financial services to the poor. Policy makers, development experts, researchers from academics, including practitioners, believed that poor people are too poor to save and are unbankable. Savings were not considered as sources of loanable capital. Donors were considered as the only source of loan fund, which encouraged dependency. The low lending interest rates were also discouraging the saving products of the institutions. As a result, the micro-credit programs in Ethiopia were unsustainable and failed to promote saving culture.

The Agricultural and Industrial Development Bank (AIDB), NGOs and cooperatives which delivered financial services to the urban and rural poor before the issuance of regulatory microfinance legislation in 1996 were not real financial intermediaries, but 
rather tools of distributing donor or government funds to a target population in order to increase agricultural production and productivity. The study of ACDI/CEE (1995) recommended that the government should develop national standards for NGO credit schemes or programs. Another study by Pischke et al. (1996) also recommended that NGOs offering credit and other financial services should be subject to national standards, and that the adoption of appropriate standards could improve their performance.

Given the above problems of AIDB, NGOs and the collapse of the service cooperatives in Ethiopia, it was time for the policy makers and individuals involved in development activities to rethink and redesign new strategies for the delivery of financial services to poor households through sustainable financial institutions. This required a redefinition and reorientation of the mission, vision and objectives of the lending institutions that usually provided only micro-credit services. The most important change in direction was building a sustainable financial service delivery system followed by mobilizing savings; charging market interest rates on loans sufficient to cover operational costs; applying strict financial discipline through strict loan recovery procedures; developing proper lending methodologies; reducing transaction costs and increasing outreach. The experiences of some sustainable microfinance institutions in Asia, Latin America, and Africa were also useful in directing the changes in the delivery of financial services to the poor in Ethiopia.

The need to promote more sustainable microfinance institutions in Ethiopia necessitated a regulatory framework. This need brought the activities of the MFIs under Ethiopia's monetary and financial policy framework. Proclamation No. 40/1996 indicates the requirements of licensing microfinance institutions by empowering the NBE to take charge of this and supervising them (see Wolday Amha, 2005 for the details).

There are currently 26 microfinance institutions registered under the NBE. Although illegal as per the law of the country, some NGOs, donors and government departments, still deliver financial services to the poor through various projects and programs which distort the markets. A good example is the micro-credit program which promotes micro-enterprises through the regional trade and industry bureaus.

Delivering financial services to the rural and urban households through sustainable financial institutions in Ethiopia has been based on the best practices around the world. Some of the key elements or factors which are required in establishing sustainable and efficient microfinance institutions include increasing outreach, operational and financial sustainability, development of demand driven financial products, institutional capacity and the capacity to mobilize resources. These are discussed in the following sections. 


\section{The relationship between growth of outreach and financial and productivity indicators of the Ethiopian microfinance institutions}

Outreach measures the extent to which an MFI has succeeded in reaching its target clients and met the demand of clients for financial services (Yaron, 1992). The scale of outreach is the number of clients reached by MFIs, while the depth of outreach gives the type of clients and the level of poverty of the clients reached. Growth of outreach of the MFIs involves: (i) a permanent increase in the size, scale, and complexity in activities and the various results being achieved by MFIs overtime. This includes increases in number of clients, outstanding loan portfolio and turnover, size of savings, etc. (ii) the changes in character of the finance providers. This would mean the transformation of the institution (graduation of a financial provider to become a regulated financial organization), improving and upgrading the capacity of an institution and obtaining improved levels of sustainability.

Growth of outreach is desirable as it would reduce poverty and attain its operational and financial sustainability MFls. Although growth of outreach has risks (unless planned and managed very well), it has also positive implications for financial institutions. In general growth in outreach

- enables the MFls to reach large number of clients and it is the key to make sound impact on reducing poverty,

- reduces average operating cost of MFIs by reducing/eliminating losses, and not by increasing lending interest rates;

- improves operational and financial sustainability.

- $\quad$ helps MFIs to satisfy their client's need through various services.

- gives better image of MFls to attract loanable fund from banks for their expansion; and

- increases the borrower's willingness to repay.

Growth in outreach is one of the prime objectives of Ethiopian MFIs. However, unless it is well organized and planned, rapid growth may have negative implications such as

- increase in loan arrears due to rapid growth in new borrowers, who are more risky than well-established borrowers and difficulties in credit monitoring;

- mismatch between organizational and skill capacity and rapid expansion;

- decline in portfolio quality

- incompatibility between the objective of reaching the poorest and increasing the number of clients. 
Moreover, the scattered settlement of the rural households and the problem of accessing them for communication have negative effect on growth.

\subsection{Growth of outreach of Ethiopian MFIs}

Outreach is measured in terms of the number of active clients (with outstanding loan), loan size, number of saving clients, volume of savings, percentage of loans to clientele below poverty line, percentage of female clients, range of financial and nonfinancial services offered to the poor, the level of transaction costs levied on the poor and the extent of client satisfaction with respect to financial services. In the last ten years, the MFIs in Ethiopia have shown a remarkable progress in terms of outreach and performance. However, the twenty six MFIs meet only less than 20 percent of the demand for financial services of the active poor. This indicates that there is significant unmet potential demand for microfinance services in Ethiopia.

]

Currently, some of the MFIs are at the startup stage where their clients are less than five thousand and require sound support to build their capacity so that they can increase their client base. There are also emerging MFIs with clients between 5,000 and 20,000, where their emphasis is on consolidating their activities to improve the quality of portfolio, performance and increase outreach. There are also MFIs that deliver financial services to 20,000 to 50,000 clients. These are MFls that are growing and with the right support, they could become mature and sustainable MFIs. Mature sustainable MFIs, in the Ethiopian context, would typically have more than 50,000 clients. Four of the largest MFIs in Ethiopia are in this category (see the details in Annex 16).

As of June 2005, the twenty six MFIs registered under the National Bank of Ethiopia had an active loan portfolio of about 1.5 billion Birr (173 million USD) delivered to $1,211,305$ active clients (Figure 1). This does not include the loans delivered to purchase fertilizer and improved seeds by the two largest MFIs. They also mobilized about 501million Birr (58 million US dollars) of savings (Annex 16). The clientele served by the MFIs in Ethiopia are mainly the rural poor. About 38 percent of the clients of the MFIs are female. The average loan size is about 1000 Birr (116 USD), which reveals that MFIs in Ethiopia focus on the active poor. The MFIs have attained significant growth in outreach in a brief period of time. Between 2001 and 2005, the number clients, volume of loan portfolio and savings increased by $263 \%, 479 \%$, and $206 \%$, respectively (Figure 1 and 2 ) 
Figure 1: Number of clients in the 21 MFIs in Ethiopia, 2001-2005

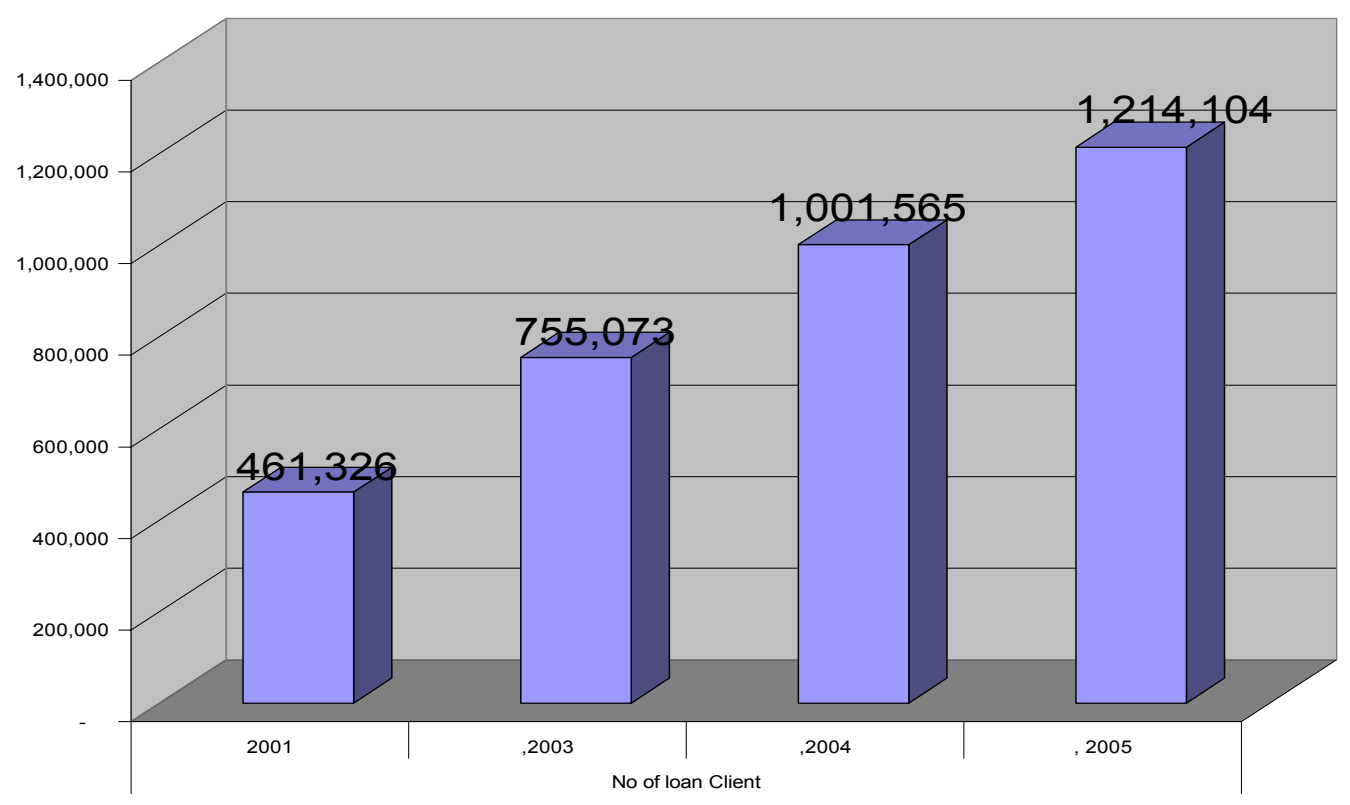

Figure 2: Value of loan portfolio and savings of the 21 MFIs in Ethiopia, 2001-2005.

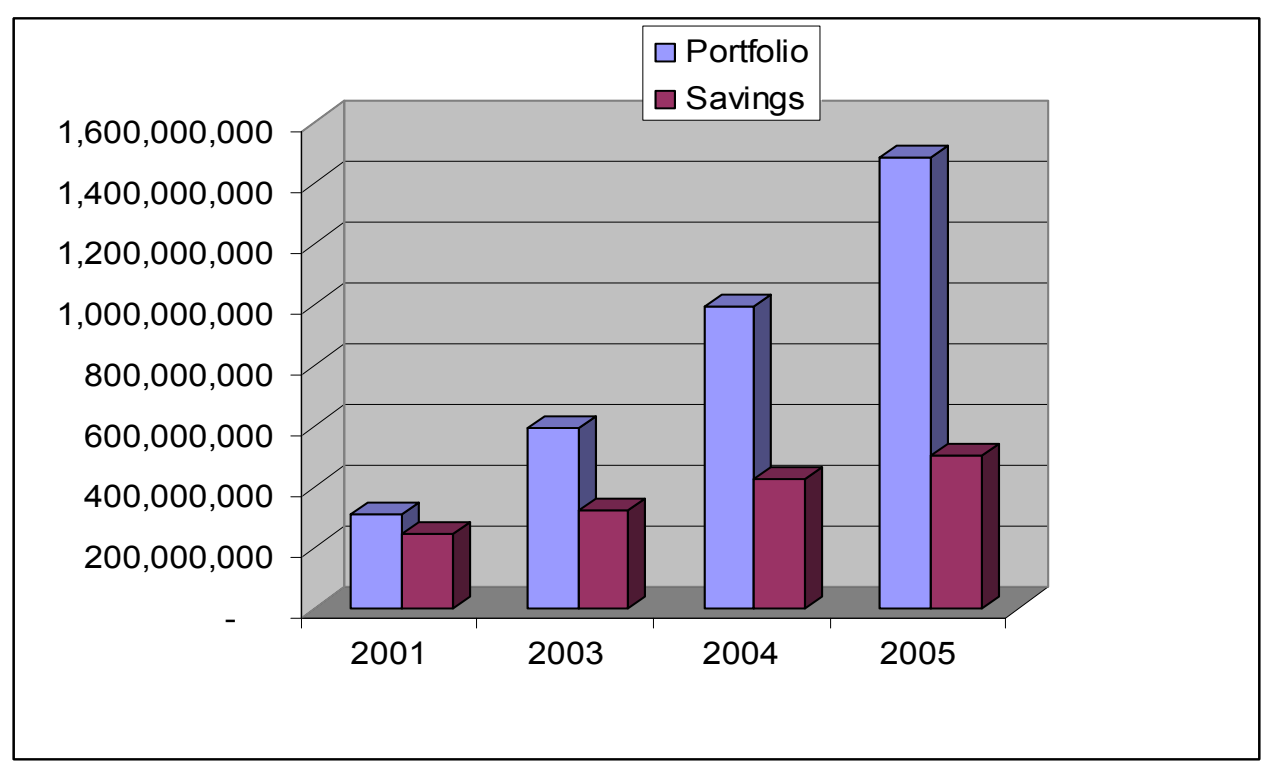


The lending interest rate of MFIs in Ethiopia varies between 9 percent per yeardeclining rate-to 24 percent-flat rate. The lending interest rates of MFIs in Ethiopia are relatively lower than in other Sub-Saharan countries. In fact, the lending interest rates of some of the MFIs are so low to cover their operation costs. This affects their sustainability negatively. The financial reports of some branches and sub-branches of MFIs reveal that they are operationally sustainable. These sustainable branches and sub-branches even question why they should subsidize unprofitable branches and sub-branches of an MFI, which is normal in the Ethiopian MFIs. It is clear that MFIs that focus on poverty reduction and targeting the rural poor do have high operational costs that reduce their profit margin. This issue has emerged as one of the challenges of the MFIs in Ethiopia. It must be noted that the financial sustainability objective of MFIs complements the social objectives.

Ethiopia has a clear regulatory framework where the MFls are allowed to mobilize savings starting from day one of their registration or after receiving their license from the National Bank of Ethiopia. The experience of Ethiopian MFIs in mobilizing savings is encouraging. As of June 2005, gross savings as percentage of the loan outstanding was about 33 percent. Another indicator of good performance of MFls is the high repayment rates which varied from 85 to 100 percent. The average repayment rate of MFIs is 96 percent. There is a reasonable client/loan portfolio to field staff ratio, however this varies from one MFI to another (see annex 1-15).

\subsection{Growth in outreach of MFIs vis-a-vis financial sustainability, productivity and portfolio quality indicators}

Although increasing the growth of outreach to reach large number of clients and make sound impact on poverty reduction is the overriding objective of MFIs in Ethiopia, it does not make sense if these institutions are unstable, unsustainable, unprofessional and inefficient. If an MFI is not sustainable due to its entire emphasis on social objectives, it will break down and foster unhealthy messages to the entire microfinance industry and distort the financial market. Poor people will learn that is foolish to repay a loan, and they will be hesitant to deposit their savings in such institutions (Krahnen and Schmidt, 1994). Thus, an MFI must be structured and run in such a way that it can survive on its own. This implies that the growth in outreach of MFIs should be examined against profitability, efficiency, productivity, and portfolio quality.

Sustainability, which shows the ability of the MFIs to cover their total expenses from their own financial service operations, has not been a major objective of MFIs in 
Ethiopia at the initial stage. However, currently, a large number of MFIs in Ethiopia have achieved significant progress in terms of sustainability. In 2004, 12 out of 15 MFIs were operationally sustainable (Annex 1-15), while 5 out of the 15 were financially sustainable. It is safe to conclude that MFIs in Ethiopia are in transition from subsidized poverty reduction lending to commercially oriented lending. On top of the financial and operational sustainability, we need to consider institutional sustainability which includes efficiency of service delivery, capacity to manage qualified, motivated and innovative staff, good governance, in-built efficient systems, etc.

Table 1: Growth of outreach and sustainability, 2003 - 2004

\begin{tabular}{lccccc}
\hline \multirow{2}{*}{ MFIs } & \multicolumn{2}{c}{$\%$ Change in outreach } & \multicolumn{2}{c}{$\%$ Sustainability } \\
\cline { 2 - 6 } & $\begin{array}{c}\text { Number of } \\
\text { active } \\
\text { borrowers }\end{array}$ & $\begin{array}{c}\text { Gross loan } \\
\text { portfolio }\end{array}$ & $\begin{array}{c}\text { Savings } \\
\text { balance }\end{array}$ & $\begin{array}{c}\text { Operational } \\
\text { self- } \\
\text { sufficiency }\end{array}$ & $\begin{array}{c}\text { Financial } \\
\text { self- } \\
\text { sufficiency }\end{array}$ \\
\hline Meklit & $10 \%$ & $38 \%$ & $41 \%$ & $24 \%$ & $-9 \%$ \\
AVFS & $69 \%$ & $32 \%$ & $63 \%$ & $-19 \%$ & $-3 \%$ \\
Wasasa & $140 \%$ & $136 \%$ & $155 \%$ & $4 \%$ & $9 \%$ \\
Buusa & $-7 \%$ & $0 \%$ & $63 \%$ & $-4 \%$ & $-7 \%$ \\
Eshet & $48 \%$ & $91 \%$ & $85 \%$ & $49 \%$ & $48 \%$ \\
Peace & $43 \%$ & $48 \%$ & $62 \%$ & $89 \%$ & $78 \%$ \\
Gasha & $26 \%$ & $109 \%$ & $52 \%$ & $19 \%$ & $11 \%$ \\
SFPI & $19 \%$ & $34 \%$ & $10 \%$ & $-2 \%$ & $-2 \%$ \\
Sidama & $-12 \%$ & $10 \%$ & $18 \%$ & $45 \%$ & $38 \%$ \\
AdCSI & $123 \%$ & $369 \%$ & $108 \%$ & $21 \%$ & $-10 \%$ \\
Wisdom & $63 \%$ & $60 \%$ & $39 \%$ & $30 \%$ & $12 \%$ \\
OMO & $7 \%$ & $28 \%$ & $24 \%$ & $20 \%$ & $27 \%$ \\
OCSSCO & $40 \%$ & $38 \%$ & $46 \%$ & $60 \%$ & $47 \%$ \\
ACSI & $21 \%$ & $49 \%$ & $34 \%$ & $30 \%$ & $14 \%$ \\
DECSI & $49 \%$ & $103 \%$ & $17 \%$ & $19 \%$ & $31 \%$ \\
\hline
\end{tabular}

Source: AEMFI, 2005

Table 1 shows that MFIs in Ethiopia have been registering significant growth in outreach, in terms of number of active borrowers (ranging from $-7 \%$ in Bussa MFI to $140 \%$ in Wasasa MFI), gross loan portfolio (from $0 \%$ in Bussa MFI to $369 \%$ in ADCSI) and mobilization of savings (17\% in DECSI to $155 \%$ in Wasasa MFI). Most of the young MFIs grew quickly which is partly the result of the drive to get their operations to optimal size quickly, so that they can reap the benefits of economies of scale. The growth in outreach was accompanied by a significant increase in operational self-sufficiency (12 out of the $15 \mathrm{MFIs}$ ) and financial self-sufficiency (10 
out of 15 MFIs). Thus, there was a substantial growth in outreach and improvement of operational and financial sustainability within one year (2003-2004).

Table 2: Growth of outreach and efficiency 2003 - 2004

\begin{tabular}{lccccc}
\hline \multirow{2}{*}{ MFIs } & \multicolumn{2}{c}{$\%$ Change in outreach } & \multicolumn{2}{c}{$\%$ Change in efficiency } \\
\cline { 2 - 5 } & $\begin{array}{c}\text { Number of } \\
\text { active } \\
\text { borrowers }\end{array}$ & $\begin{array}{c}\text { Gross } \\
\text { loan } \\
\text { portfolio }\end{array}$ & $\begin{array}{c}\text { Savings } \\
\text { balance }\end{array}$ & $\begin{array}{c}\text { Operating } \\
\text { expense/ loan } \\
\text { portfolio }\end{array}$ & $\begin{array}{c}\text { Personnel } \\
\text { expense/ loan } \\
\text { portfolio }\end{array}$ \\
\hline Meklit & $10 \%$ & $38 \%$ & $41 \%$ & $7.70 \%$ & $-2.30 \%$ \\
AVFS & $69 \%$ & $32 \%$ & $63 \%$ & $-11 \%$ & $-12 \%$ \\
Wasasa & $140 \%$ & $136 \%$ & $155 \%$ & $6 \%$ & $10 \%$ \\
Buusa & $-7 \%$ & $0 \%$ & $63 \%$ & $-5 \%$ & $1 \%$ \\
Eshet & $48 \%$ & $91 \%$ & $85 \%$ & $-41 \%$ & $-39 \%$ \\
Peace & $43 \%$ & $48 \%$ & $62 \%$ & $-15 \%$ & $-12 \%$ \\
Gasha & $26 \%$ & $109 \%$ & $52 \%$ & $-41 \%$ & $-43 \%$ \\
SFPI & $19 \%$ & $34 \%$ & $10 \%$ & $-15 \%$ & $-9 \%$ \\
Sidama & $-12 \%$ & $10 \%$ & $18 \%$ & $-16 \%$ & $-15 \%$ \\
AdCSI & $123 \%$ & $369 \%$ & $108 \%$ & $-44 \%$ & $-41 \%$ \\
Wisdom & $63 \%$ & $60 \%$ & $39 \%$ & $-4 \%$ & $12 \%$ \\
OMO & $7 \%$ & $28 \%$ & $24 \%$ & $17 \%$ & $17 \%$ \\
OCSSCO & $40 \%$ & $38 \%$ & $46 \%$ & $-16 \%$ & $-13 \%$ \\
ACSI & $21 \%$ & $49 \%$ & $34 \%$ & $-18 \%$ & $-20 \%$ \\
DECSI & $49 \%$ & $103 \%$ & $17 \%$ & $-37 \%$ & $-38 \%$ \\
\hline SOUFe: & & & & & \\
\hline
\end{tabular}

Source: AEMFI, 2005

Efficiency measures the cost incurred by MFIs to carry out their financial services. The ratio of operating expense to loan portfolio indicates how much an MFI costs to keep 1 Birr of the portfolio out in the hands of clients (a declining ratio is an improvement in efficiency). Since salary and salary related expenses represent a significant percentage of the operating costs of MFIs, a decrease in personnel expense to loan portfolio will have a positive impact on financial sustainability. As MFIs mature and adopt best practices in operational and financial management techniques, efficiency will increase. However, in the initial stages of a strong growth phase, efficiency can be expected to worsen as an MFI incurs new expenses, such as building offices, training cost and additional salary expenses.

Ethiopian MFIs reach more clients at lower cost as is reflected by the ratio of operating expense to loan portfolio which varied from $41.8 \%$ in Bussa Gonoffa MFI to $3.8 \%$ in Dedebit Credit and Saving Institution (2004). This could be partly explained by the group lending methodology applied almost in all MFIs. In the same year, the personnel expense to loan portfolio varied from 21.9\% in Bussa Gonoffa MFI to $2.3 \%$ in Dedebit it and Saving Institution (Annex 1-15). The results in Annex 1-15 indicate 
that the larger an MFI is in terms of outreach, the lower will be its efficiency ratio. Table 2 reveals that, with the exception of three MFIs, there were consistent declines in operating expense to loan portfolio ratio as a result of significant increase in outreach. Similar trend was observed in the personnel expense to loan portfolio ratio, that is, with the exception of four MFIs, the ratio declined as a result of increased outreach.

Table 3: Growth of outreach and productivity $2003-2004$

\begin{tabular}{lccccc}
\hline & \multicolumn{2}{c}{ \% Change in outreach } & \multicolumn{2}{c}{ Change in productivity } \\
\cline { 2 - 6 } & $\begin{array}{c}\text { Number of } \\
\text { active } \\
\text { borrowers }\end{array}$ & $\begin{array}{c}\text { Gross loan } \\
\text { portfolio }\end{array}$ & $\begin{array}{c}\text { Savings } \\
\text { balance }\end{array}$ & $\begin{array}{c}\text { Borrowers } \\
\text { per staff } \\
\text { member }\end{array}$ & $\begin{array}{c}\text { Borrowers } \\
\text { per loan } \\
\text { officer }\end{array}$ \\
\hline Meklit & $10 \%$ & $38 \%$ & $41 \%$ & $-10 \%$ & $-17 \%$ \\
AVFS & $69 \%$ & $32 \%$ & $63 \%$ & $35 \%$ & $27 \%$ \\
Wasasa & $140 \%$ & $136 \%$ & $155 \%$ & $24 \%$ & $29 \%$ \\
Buusa & $-7 \%$ & $0 \%$ & $63 \%$ & $-17 \%$ & $-11 \%$ \\
Eshet & $48 \%$ & $91 \%$ & $85 \%$ & $25 \%$ & $23 \%$ \\
Peace & $43 \%$ & $48 \%$ & $62 \%$ & $8 \%$ & $-14 \%$ \\
Gasha & $26 \%$ & $109 \%$ & $52 \%$ & $21 \%$ & $26 \%$ \\
SFPI & $19 \%$ & $34 \%$ & $10 \%$ & $-2 \%$ & $-2 \%$ \\
Sidama & $-12 \%$ & $10 \%$ & $18 \%$ & $-9 \%$ & $-8 \%$ \\
AdCSI & $123 \%$ & $369 \%$ & $108 \%$ & $49 \%$ & $41 \%$ \\
Wisdom & $63 \%$ & $60 \%$ & $39 \%$ & $10 \%$ & $-18 \%$ \\
OMO & $7 \%$ & $28 \%$ & $24 \%$ & $1 \%$ & $1 \%$ \\
OCSSCO & $40 \%$ & $38 \%$ & $46 \%$ & $39 \%$ & $372 \%$ \\
ACSI & $21 \%$ & $49 \%$ & $34 \%$ & $8 \%$ & $14 \%$ \\
DECSI & $49 \%$ & $103 \%$ & $17 \%$ & $15 \%$ & $36 \%$ \\
\hline
\end{tabular}

Source: AEMFI, 2005

As an MFI builds up its staff and its lending experience, the productivity of its lending operations is likely to grow rapidly. Each loan officer can administer a progressively larger loan portfolio with more clients and larger loans, and overhead costs can be spread over a larger portfolio for an MFI. In 2004, the ratio of borrower per loan officer varied from 214 in Gasha MFI to 518 in PEACE MFI. In the same year, the ratio of borrower per staff member varied from 89 in Sidama MFI to 388 in DECSI (Annex 1-15).

Table 3 indicates that out of the 13 MFls which showed significant increase in the number of clients, 9 of them registered significant increase in the ratio of borrower per loan officer. The majority of the MFIs increased their productivity indicators (borrower per staff and borrower per loan officer) as a result of expansion or increase in outreach. 
The critical question in the performance of MFIs is whether they will be able to significantly expand outreach and maintain the quality of portfolio. The portfolio at risk measures the percentage of the adjusted outstanding gross loan portfolio that is at risk (a decreasing ratio is an improvement in quality). This ratio is the most accepted indicator of portfolio quality. It shows the portion of the portfolio that is contaminated by arrears and therefore at risk of not being repaid. Best practice uses the 30 days cut-off. In 2004, the portfolio at risk of the $15 \mathrm{MFIs}$ varied from $0.1 \%$ in PEACE and Wasasa MFIs to $26.2 \%$ in Sidama MFI (Annex 1-15). Out of the 15 MFIs, eleven had less than $5 \%$ portfolio at risk, which was encouraging. However, the four MFIs with large portfolio at risk should take immediate actions to reduce the portfolio at risk to an acceptable percentage.

Table 4 reveals that out of the 13 MFIs which registered significant growth in outreach, 9 showed remarkable decline in their portfolio at risk. The results reveal that, even though many MFls increased outreach, they still maintained or even improved their portfolio quality. However, given the same amount of arrears, if an MFI increases its loan disbursement significantly and writes-off its non-performing loans, there could be an improvement in the portfolio at risk which might not show the real picture of improvement in the quality of its portfolio. Thus, the results regarding portfolio quality in Table 4 should be interpreted with care.

Table 4: Growth of outreach and portfolio quality $2003-2004$

\begin{tabular}{lccccc}
\hline \multirow{2}{*}{ MFIs } & \multicolumn{2}{c}{$\%$ Change in outreach } & \multicolumn{2}{c}{ \% Change in portfolio quality } \\
\cline { 2 - 6 } & $\begin{array}{c}\text { Number of } \\
\text { active } \\
\text { borrowers }\end{array}$ & $\begin{array}{c}\text { Gross loan } \\
\text { portfolio }\end{array}$ & $\begin{array}{c}\text { Savings } \\
\text { balance }\end{array}$ & $\begin{array}{c}\text { Portfolio at } \\
\text { risk> 30 days }\end{array}$ & $\begin{array}{c}\text { Write-off } \\
\text { ratio }\end{array}$ \\
\hline Meklit & $10 \%$ & $38 \%$ & $41 \%$ & $82 \%$ & $18 \%$ \\
AVFS & $69 \%$ & $32 \%$ & $63 \%$ & $-80 \%$ & $-77 \%$ \\
Wasasa & $140 \%$ & $136 \%$ & $155 \%$ & $-98 \%$ & $275 \%$ \\
Buusa & $-7 \%$ & $0 \%$ & $63 \%$ & $-32 \%$ & $-62 \%$ \\
Eshet & $48 \%$ & $91 \%$ & $85 \%$ & $80 \%$ & \\
Peace & $43 \%$ & $48 \%$ & $62 \%$ & $-50 \%$ & \\
Gasha & $26 \%$ & $109 \%$ & $52 \%$ & $-75 \%$ & $-25 \%$ \\
SFPI & $19 \%$ & $34 \%$ & $10 \%$ & $66 \%$ & $160 \%$ \\
Sidama & $-12 \%$ & $10 \%$ & $18 \%$ & $-10 \%$ & \\
AdCSI & $123 \%$ & $369 \%$ & $108 \%$ & $164 \%$ & $-44 \%$ \\
Wisdom & $63 \%$ & $60 \%$ & $39 \%$ & $-34 \%$ & $-18 \%$ \\
OMO & $7 \%$ & $28 \%$ & $24 \%$ & $-51 \%$ & $-1 \%$ \\
OCSSCO & $40 \%$ & $38 \%$ & $46 \%$ & $-36 \%$ & \\
ACSI & $21 \%$ & $49 \%$ & $34 \%$ & $-70 \%$ & $-31 \%$ \\
DECSI & $49 \%$ & $103 \%$ & $17 \%$ & $-62 \%$ & $-42 \%$ \\
\hline SOUFE AEMFI & $2005 \%$ & & & & \\
\hline
\end{tabular}




\section{Factors affecting the growth or outreach of MFIs}

There are a number of factors that affect the growth of MFIs in Ethiopia. These include institutional capacity, availability of loanable funds, policy and regulatory environment, macro, meso and micro level economic performance, demand side problems related with the sustainability of clients of MFIs and donor support. The following section attempts to review the factors affecting growth by relating them to the Ethiopian context.

\subsection{Institutional capacity of MFIs}

Institution building, being the key factor for growth of MFIs, is a process which ranges from a minimum of interference or modification to far-reaching measures to restructure, transform and build entirely new institutions. There are three basic elements that should be considered in building sustainable MFIs: Firstly, MFls must be permanently oriented towards the delivery of financial services to the majority of the unbanked households. Secondly, MFls must be viable over the medium-to-long term period. This includes the ability to cover their costs. If they are to achieve costcoverage, they must charge prices for the services they provide which the clients can afford to pay and which are also sufficient to cover the full costs of running the institutions. Thirdly, MFIs should be able to keep their costs - which they will pass on to their clients via the prices they charge them - as low as possible (Schmidt and Zeitinger, 1996).

One of the main objectives of institution building is to upgrade MFIs so that they increase their capacity and reach large number of clients on a sustainable basis. This has two components, namely growth and qualitative transformation. It is important that MFIs grow rapidly in order to expand the scope of their operations and acquire expertise in lending, thus allowing them to reduce their costs to the extent that they become acceptable to pass them on, in full, to borrowers. Transformation partly refers to changes in the legal status of MFIs (say from an MFI to rural bank or from NGO to licensed depositing MFI), or changes in the relationship between an MFI and the mother NGOs, or changes in the internal structure, as well as the kinds of financial services, which they offer to clients. The major factors that need to be addressed in building the institutional capacity of MFIs include the following:

\section{(a) Good governance}

Good governance plays an important role in increasing outreach, improving transparency, accountability, sustainability, profitability, efficiency, effectiveness, 
responsibility and responsiveness of MFIs to changing environments. Effective governance depends on both forms- the structures and processes of control, and content-and the specific individuals involved, particularly in the leadership. For example, board members are expected to have skills as leaders, visionary thinkers, and managers. They should have independent mind, genuine commitment, technical expertise and experience relevant to manage MFIs (financial, legal, marketing, etc), and willingness to set time to participate in the activities of an MFI. Moreover, although the formal institutional (legal) context determines the broad framework for the governance structure - for example, the roles and responsibilities of directors of MFIs - it rarely appears to play the major role of good governance.

In principle, private ownership in combination with an unrestricted profit orientation appears to be the basis for securing an efficient provision of financial services as long as banking supervision functions properly and competition ensures that no single institution is in a position to charge monopolistic prices. In a company for-profit, shareholders own the assets and a board of directors has a fiduciary responsibility to those shareholders for the effective use and protection of those assets. The board's competency in exercising that fiduciary role can be measured relatively easily in terms of the financial performance of the institution. Where performance is unsatisfactory, owners will be expected to take action, with the ultimate sanction of dismissing the board. There are two key points here: First, in a company for-profit, there is generally a performance framework which is readily understood by senior management, the board and others. Second, the owners of the assets are empowered to take action where performance is unsatisfactory. However, in many of the MFIs in Ethiopia which are not-for-profit organizations, ownership is often unclear. Although public money is invested in most of the MFIs, there are not clearly definable owners of the assets who can take action where performance is poor. Moreover, the performance criteria of these MFIs are often both poorly defined and difficult to measure. This is especially the case where different stakeholders who may be represented on a board have diverging objectives.

Some argue against private ownership of MFIs in Ethiopia stating that although granting credit to poor borrowers may turn out to be a profitable business in a liberalized financial system over the medium term, financial entrepreneurs are likely to find out market niches to be more profitable than small and micro enterprise lending. This might lead them to turn to other groups of customers and thus give up the delivery of financial services to the poor households and marginalized areas.

The issue of governance and ownership in the Ethiopian MFIs is a serious issue which needs to be addressed immediately. With the exception of one MFI, the shareholders are not real shareholders who share the benefits of the operation of an 
MFI. The issue of accountability and fiduciary responsibility is questionable. MFIs in Ethiopia are not interested in selling shares and attracting other shareholders. Since board members are predominately NGO staff or government employees, there is a tendency to promote and share the vision and mission of the mother-NGO and government development interventions. The law prohibits foreign organizations and non-Ethiopians in participating as shareholders in the sector. According to the study by Itana et al., (2003), there are no regular board meetings and self-evaluation of boards in many of the MFIs. Moreover, board members have limited knowledge and capacity to support management and monitor the performance of MFIs.

\section{(b) Human resource}

Microfinance institutions are highly labor intensive. Labor costs, very often, account for more than half of their total cost of administration. A crucial element of an MFI's capacity therefore depends directly on the effectiveness of its staff. The direct productivity in terms of the size of portfolio and number of clients which can be handled effectively by a front-line loan officer is enormously important for its sustainability. Although productivity depends on many factors, the performance of the individual officer is a major determinant. The ability to train, motivate and effectively manage its lending officers is at the core of its capacity. The capacity building process should involve training and re-training of all staff including the board of directors. Thus, appropriate career development programs, with on-going training and support, are essential ingredients of the business plan of a successful MFI.

A comprehensive training need assessment for sub-branches, branches, head office, clients and board members of the MFls was conducted in 2003 with the support of the Rural Financial Intermediation Program (RUFIP). The findings revealed that there is huge gap in terms of staff training needs in the industry to ensure growth and sustainability. The training needs identified in the study are aimed at addressing the challenges of lending methodologies, understanding the community, product development, financing agriculture, saving mobilization, internal control and audit, MIS, financial management, gender sensitization and governance. Detailed training modules and training programs were prepared for various categories of staff (RUFIP and AEMFI, 2003).

Moreover, a system of incentives (performance-based remuneration such as profit sharing, collection fees, etc and efficiency wages as compatible) should be introduced to meet the objectives of financial sustainability and increasing outreach. This includes fixed salary plus a bonus or incentive payments that is a function of some observable variable or performance indicators, such as profits or loan installments recovered. However, in the Ethiopian context, although MFIs complain 
about the high turnover of senior staff, there has not been a concerted effort to address the issue of staff incentives.

\section{(c) Systems}

Effective systems underpin both the efficient implementation of innovative methodologies and the management of an MFI. Significant reduction in transaction costs can be achieved through the use of innovative lending methodologies, ensuring good client service, maintaining the integrity of the operations to ensure accuracy and prevent fraud (through an appropriate internal and external control system) and generating the information necessary to mange the portfolio. The availability of accurate, relevant and timely information is essential for both front-line staff and the varying levels of management to be able to take effective actions.

Information technology (IT) has a potential role in increasing outreach and improving sustainability of an MFI. Efficiency achieved through the use of information technology has an immediate bearing on transaction costs and potentially rendering new markets or product. Beyond its use in portfolio tracking (the ability to detect and follow-up rapidly on loan defaults) and accounting, IT can also be used to support products directly. Nevertheless, it does not appear that the full computerization of an MFI operation is a prerequisite for the sustainability in all contexts. There are cases in Bangladesh, India, Ethiopia and others, where much of the loan tracking is carried out manually without apparently undermining sustainability. However, it is clear that IT provides better management information which can significantly improve managerial decision making at various levels. Although there are efforts by some MFIs in Ethiopia to apply software such as TMS, Loan Performer, and Emerge to track financial and operational information, there is a need in the industry to address the issue holistically.

In the context of Ethiopian MFIs, technology has served to mange information (MIS), that is, primarily on the back end. This has helped MFls to standardize their operations, produce timely and transparent financial reports on their operations and otherwise needed. However, there are huge opportunities where Ethiopian MFIs can use new technologies in the front end. Among the technologies that available to be used in the front end include: magnetic stripe and chip (smart) cards, point of sales devices, ATMs, cell phones, satellite communications, the internet, credit scoring, data mining, biometric recognition and more. These technologies will require MFIs to redesign their business models and educate their employees and customers to master new ways to deliver and receive services. Such changes will not always be easy, but the benefits will be dramatic. 


\subsection{Developing demand driven financial products and methodologies}

MFIs need to increase their scope and operation by searching for new markets and deepen their penetration by broadening the range of financial services offered to households. We believe that the poor in both the rural and urban areas are lucrative customers worth wooing for MFIs. The microfinance providers should shift from the traditional supply-driven financial products to demand-driven products which involve market research and new product development. Households are not homogeneous and within one group, different segments appear with different needs. For example, micro enterprise operators in urban and rural areas have different financial needs at different times. Using a product development process that is client centered allows meeting both the financial and social goals of an MFI. Focusing on what is of value to the client influences the operational efficiency as well as product design, increases client satisfaction and retention, and profitability of MFIs. Products tailored to client's financing needs have greater impact in helping them manage the volatility inherent in the sector within which they work. Designing product terms tied to client cash flow also improves the repayment capacity and allows the MFIs to sustain their operation.

The major factors which affect product development in the Ethiopian MFIs include:

(a) the regulatory framework which restricts MFIs to limited financial products;

(b) huge demand for microfinance services leading to little incentive for MFIs to develop new products or modify existing ones;

(c) lack of competition in the industry;

(d) donor and government intervention influencing the type of financial products; and

(e) limited technical skill and financial resources to test new products (Wolday, 2002).

As indicated earlier, one of the critical issues in product development is the weak capacity of MFIs, MFI's failure to establish the necessary institutional setup to develop financial products and professional skills for their staff in the area of market research, product development and risk management, could limit their capacity to identify and respond to changes in the market and limit their growth. There is a consensus in the industry to develop innovative lending methodologies and financial products which match the needs of rural and urban households. Underpinning all methodologies for delivering microfinance services is the need to minimize transaction costs. A wide variety of mechanisms exist but many can be seen to belong to the following three broad categories 


\section{(a) Group lending methodology}

The solidarity group based lending approach, often associated with the Grameen Bank in Bangladesh, is an innovative lending methodology which minimizes transaction costs (in the process of screening clients). It also addresses the problems of physical collateral requirement of conventional banks through intra-group guarantees and reduces the cost of administration by addressing the loan needs of clients collectively. In order to obtain a loan, members of a group cross guarantee one another's borrowing, as they would have reliable personal knowledge of their fellow group members. Actually, the group lending methodology is mainly based on peer group pressure (social capital). When a borrower defaults on a loan, the lender will look first to the guarantees from the members of the group. Frequently the crossguarantees, which members of the group provide towards one another, will be supported by compulsory savings. This is the dominant lending approach used by almost all MFIs in Ethiopia. Although the group lending methodology has been a very useful tool in expanding the growth in outreach of MFIs in Ethiopia, clients have complaints on the methodology.

\section{(b) Individual lending}

There is no "one size fits all" approach in microfinance. An MFI can use a combination of various lending methodologies which match with the needs and economic activities of its clients. As indicated earlier, there are complaints on the group lending methodology in Ethiopia, for instance, why should clients be penalized for a colleague who defaulted, it excludes the poorest households, it encounters difficulties as the size of the loan increases and does not necessarily fit to the needs of MSE operators and others who need relatively larger loan size, etc.

In response to the above problems and the needs identified by market research, MFIs have been developing individual lending methodologies based on traditional and nontraditional collateral. Non-traditional collateral includes household and business assets such as radio, TV, bicycle, sewing machine, etc. The conventional approach used by commercial banks to screen borrowing proposals, based on analysis of historical performance and business plans are usually inappropriate for microfinance. Clients of MFIs hardly keep reliable records and are unable to produce meaningful business plans.

The efficacy of the individual lending methodology depends on various factors such as strength of the legal system in enforcing contracts, the ability of an MFI to enforce the lending agreements in the case of defaults, information flow in the community and other socio-cultural issues. Ethiopian MFls are recently introducing individual lending 
methodology to provide loans to MSE operators who require larger loans (above 5,000 Birr). Some MFIs such as DECSI have also reduced the group size from five to three.

\section{(c) Community based or user-owned/managed lending}

There is a very significant potential for lowering transaction costs through financial organizations which are both owned and managed by communities. These include the Savings and Credit Cooperatives (SACCOs), Credit Unions, Village banks, Rotating Savings and Credit Cooperatives (ROSCAs), burial societies, etc. Such organizations are able to draw directly on both local knowledge about borrowers and social capital to reduce the transaction costs and the associated risk. Since the above organizations are locally owned, the potential loss of social capital in the event of default can represent a powerful disincentive to default. Transaction costs associated with the administration of financial products are reduced due to the geographic proximity of the organization to its clients and the lower labor costs by using local staff or members themselves.

While member-owned institutions are prevalent in many rural and urban areas, including remote areas, and serve poorer segments of the population in Ethiopia, they have limitations in becoming the prime financial intermediaries. Since they are selfmanaged, an appropriate form of governance needs to be developed for each type to ensure sustainability.

\subsection{Mobilizing loanable funds}

Significant investment capital is needed to develop new or moving existing institutions to increase outreach. The balance sheet of an MFI must have sufficient strength to absorb losses which can arise within long-term business cycles, without threatening its ability to meet its liabilities. Securing appropriate investment capital for growth of outreach of MFIs is not merely a question of the availability of funds, but the form of funding. The loanable funds of MFIs in Ethiopia are primarily from six sources:

(a) Mobilizing savings: Ethiopian MFIs have proved that the poor have a high propensity to save when provided with safe, accessible and convenient mechanisms. Access to saving facilities is as important as credit for the poor. Moreover, it increases the autonomy of an MFI and is one of the reliable funding sources for MFIs to finance growth and expansion. Thus, MFIs should develop business plans that would allow them to capture savings from clients and nonclients. 
(b) Equity: To get license and operate in microfinance activities, MFIs in Ethiopia are required to have a minimum of 200,000 Birr (23,000 USD) as paid-up capital. The equity investment of MFIs is very limited. There are very limited initiatives to sell equity and increase their loanable fund.

(c) Loan from formal banks: Although over liquid, the formal banks in Ethiopia were not interested in lending to MFIs. On the other hand, due to the sweet money obtained from donors, MFIs in Ethiopia were initially reluctant to access loan from banks at market rate. However, recently some MFls have shown keen interest to take loan from banks through the support of regional governments, NGOs and donors by introducing credit guarantee schemes.

(d) Rural Financial Intermediation Program (RUFIP): This particular program is financed by IFAD, ADB and the Ethiopian government to support MFIs and Saving and Credit Cooperatives (SACCOs). Out of the total fund of the program (87 million USD), $81 \%$ is allocated for loanable fund, for MFIs and rural SACCOs, and the remaining $19 \%$ for capacity building. Those MFIs, which fulfill the minimum performance requirements of the program, are eligible to take loan at $6 \%$ lending interest rate. RUFIP has been very successful in providing loanable fund, build capacity, promoting growth of their activities, improving efficiency, and enforcing the regulatory framework.

(e) Donation: MFls have been obtaining donations and grants as seed money (start-up capital) or funds for expansion from their mother NGOs. However, many of the MFIs are realizing that funding sources from NGOs and donors are becoming scarce.

(f) Income from lending activities: Although some MFIs are currently expanding their activities from own income, the interest income and fees from lending activities or operations of many MFIs in Ethiopia were not large enough to cover operational costs and finance expansions. Thus, a significant expansion of the operations of MFIs would require outside sources of funding.

\subsection{Enabling policy, legal and regulatory environment}

An enabling policy environment is important to achieve substantial outreach and attain operational and financial sustainability of MFIs. The sectoral and development policies, the commitment of governments at various levels, the performance of the macro economy (the state of the real economy related to improving the efficiency in agriculture, industry commerce, etc), the performance of the financial sector policies, the efficiency of the legal and regulatory system, fiscal and monetary system, and political system affects the growth of outreach of MFIs. 
It is argued that a dynamic economy and comparatively stable macroeconomic and political environment offers an enabling climate to the success of the MFIs. This dynamism is expected to result in high and growing demand for financial services. Stable macroeconomic conditions and low inflation do support the growth of MFIs. However, macroeconomic stability, although important, is not by itself, a sufficient condition. There are poorly performing MFIs in countries with stable macro economic conditions. If we take the example of DECSI, although the region where this MFI is operating is one of the poorest regions (with stagnant economy) in Ethiopia, its performance in the last ten years has been remarkable by all standards. This is partly due to political commitment, political stability, high degree of social cohesion and traditional social structures that facilitated the enforcement of contracts, increase outreach and efficiency.

The various policies and the commitment of the governments at various levels to support microfinance activities have direct impact on outreach and viability of MFIs. The government, to promote the industry, should have a clear microfinance strategy which will be reflected in all the development and sectoral policies. In the Ethiopian context, the government is committed to promote the delivery of microfinance services to poor households. Microfinance is considered by government as its own tool to fight poverty. This is reflected in the poverty reduction program, food security strategy, rural development program, industrial policy, etc. The effectiveness of the monitory and fiscal policies has also a direct influence on the success of microfinance activities measured in terms of outreach, productivity, efficiency and sustainability. As indicated earlier, the government of Ethiopia has implemented the Rural Financial Intermediation Program (RUFIP) by taking a loan of 87 million USD from IFAD and ADB to support the microfinance activities. This shows the real commitment of the government to promote the industry. However, although the microfinance industry needs the support of the government at various levels, this does not mean that it should involve directly in the delivery of financial services to the poor. Actually, in the Ethiopian context, this is prohibited by law.

Regulatory environment affects growth, efficiency, productivity and sustainability of MFIs. The regulatory framework of microfinance institutions in Ethiopia has played a positive role in increasing outreach and mobilizing public saving. However, the directives and the microfinance legislation (40/96) in Ethiopia need to be revised to accommodate the dynamic growth and innovations in the microfinance industry (Wolday, 2005). On the other hand, there are positive and encouraging developments in Ethiopia, where the general managers of all MFIs regularly meet with the governor of the National Bank of Ethiopia (NBE) and senior staff to discuss the problems of the microfinance industry. 
The legal framework in Ethiopia is very weak in enforcing loan contracts. Without the foreclosure legislation (which gave power to commercial banks to foreclose the property of a borrower in 30 days, if he/she defaults), the banking sector in Ethiopia would have collapsed long ago. MFIs, through their network, Association of Ethiopian Microfinance Institutions (AEMFI), have requested the National Bank of Ethiopia to revisit and amend the foreclosure legislation to include both banks and MFIs. The weak legal environment has discouraged MFIs from developing financial products focusing on individual lending methodology.

\subsection{Donor support}

The support of donors to MFIs takes mainly four dimensions, namely, (i) provision of loanable capital as grant, soft loan, etc, (ii) building the capacity of MFIs by providing training, computers, office equipment, vehicles, MIS, communication equipment, etc, (iii) advisory services, and (iv)contribute in developing and piloting innovate products that meet the needs of poor households.

It is clear that MFIs need seed money in the first year and soft loans in the second year, however, in the third year; the MFI should access loans at market interest rate. When financial self-sufficiency is attained, the institution should be transformed into a formal financial institution which is characterized by a marked increase in portfolio volume, productivity and a concomitant decline in average lending costs.

Donors in Ethiopia have been supporting almost all MFIs (with the exception of Agar Microfinance Institution) in building their capacity. Unlike many African countries, there are restrictions on the interventions of donors in the microfinance industry which include: (a) MFIs should be owned by Ethiopians, (b) donors cannot be shareholders in an MFI, and (c) if MFIs access loans from donors or foreign banks, they are not allowed to pay the interest and the principal in hard currency. Since these restrictions have direct impact on the growth of MFIs, we need to revisit the regulatory framework. On the other hand, although donors can play a positive role in increasing outreach and efficiency of MFIs, they could also distort the financial markets by injecting subsidized funds in the system. The MFIs in Ethiopia complain that some donors such as the World Bank are distorting the financial markets through its food security program. 


\subsection{Demand side}

Growth in outreach of MFls is affected by factors affecting the efficiency and productivity of active and potential clients. The education and skill of potential clients; availability of markets and working places; and growth and performance of the real sector affects the growth, portfolio quality, efficiency and productivity of MFIs. According to Geberhiwot and Wolday (2004), the most important constraints of micro and small enterprise operators were mainly related to access to markets and finance. Among the top three problems experienced in starting up their business were capital constraint, inadequate premise, demand shortage and inadequate skill. About 72 percent of the micro and 65 percent of the small enterprise operators reported lack of markets as their major constraint. Government institutions at various levels, donors, NGOs and other development partners should play a key role in addressing the demand side problems of clients.

Governments at various levels, NGOs and other development partners should also play an active role in providing non-financial services such as Business Development Services (BDS). The results of the study by Wolday and Geberhiwot (2004) indicated that there were very few BDS providers offering limited services to few MSE operators (very low outreach). MSE operators had very limited vocational and technical training (before starting business), received few short-term training, extension and counseling, and marketing services.

\section{Conclusion recommendations}

Many of the MFIs in Ethiopia have been focusing on addressing rural poverty. As rural finance providers for poor households in remote areas, MFIs have been dealing with seasonality issues, high covariant risk, low average returns, inadequate information infrastructure, large risks due to drought and others, irregular cash flows, difficult terrain, remote and illiterate clients, highly diversity, and sparse population. The performance of MFIs, in Ethiopia, be it in terms of outreach or sustainability, should be evaluated against this tough environment.

As of June 2005, the twenty six microfinance institutions registered under the National Bank of Ethiopia had an active loan portfolio of about 1.5 billion Birr (173 million USD) delivered to $1,211,305$ active clients. They mobilized about 501 million Birr (58 million US dollars) of savings. The clientele served by the MFIs in Ethiopia are mainly the rural poor. The Ethiopian MFIs have attained significant outreach in a brief period of time. Between 2001 and 2005, the number of clients, volume of loan portfolio and savings increased by $263 \%, 479 \%$, and $206 \%$, respectively. 
A large number of MFIs in Ethiopia have achieved significant progress in terms of sustainability. In 2004, 12 out of the 15 MFIs were operationally sustainable, while 5 were financially sustainable. There was a substantial growth in outreach and improvement of operational and financial sustainability within one year (2003-2004). There was also a consistent decline in operating expense to loan portfolio ratio as a result of significant increase in outreach. The majority of the MFIs increased their productivity indicators (borrower per staff and borrower per loan officer) as a result of expansion or increase in outreach. Out of the $15 \mathrm{MFIs}$, eleven had less than $5 \%$ portfolio at risk, which was encouraging. Out of the 13 MFIs which registered significant growth in outreach, 9 showed a remarkable decline in their portfolio at risk. As a result of increased outreach, many of the MFIs maintained and improved their portfolio quality.

The prospect for growth of MFls in Ethiopia is bright, particularly when growth promoting forces are put on the ground and when microfinance institutions are allowed to do what finance is supposed to do. The whole objective of microfinance should be on developing institutions that can create and provide the broad range of microfinance services that will support millions of poor people in their efforts to improve their own and their children's prospects. This is realized through development of capable and sustainable MFls. Efforts should be made to increase the efficiency of MFIs financially. They should also be made organizationally stable and more professional in order to be able to deliver financial services to millions of unbanked people permanently. This should also include the provision of financial services to pastoralist areas that currently have little or no access to microfinance services.

Managing and planning growth of MFIs in Ethiopia will require deliberate actions and strategies designed by policy makers and industry leaders. This requires careful balancing of increasing outreach and sustainability; with a parallel focus on institutional capacity; reducing costs and risks; and improving efficiency, profitability and portfolio quality. The specific interventions to increase the growth of MFIs include: (i) improving the institutional capacity of the MFIs by introducing an efficient organizational structure, (changes in organization culture, structure and systems, for instance, decentralized lending decisions) with appropriate staff incentive and reward system, improved skill of human resource, good governance, introduction of innovative financial products, and an increase of geographic expansion; (ii) creating an enabling legal, regulatory and policy environment; (iii) selective donor support; and (iv) improving the demand side of the equation. 


\section{References}

ACDI/CEE (1995). Ethiopia: Rural finance and micro-enterprise needs assessment, Washington D.C and Addis Ababa

Bezabih Emana, Kejela Gemtessa, Dhunfa Lemessa, and Gezahegn Ayele (2005) Informal finance in Ethiopia. Association of Ethiopian Microfinance Institutions (AEMFI). Addis Ababa.

Gebrehiwot Ageba and Wolday Amha (2004) Micro and small enterprise (MSE) finance: A survey experience. Proceedings of the International Conference on Microfinance Development in Ethiopia. Awassa.

Itana Ayana, Tsehay Tsegaye and Eshetu Erena (2003) Governance and ownership structure of microfinance institutions in Ethiopia. AEMFI. Occasional Paper No.8

Krahnen J.P and Schmidt R.H (1994) Development Finance as Institution Building. Westview Press, Boulder.

Pischke J.D, Itana Ayana. Edward L.N and Mesfin Nemera (1996) Ethiopia: rural credit center for economic growth. Credit Financial Sector Development Project II (FSDP II)

RUFIP and AEMFI (2003) Training need assessment of microfinance industry in Ethiopia. AEMFI. Occasional Paper No. 9

Schmidt R.H and Zeitinger C.P (1996) Prospects, problems and potential of credit-granting NGOs. Journal of International Development. Vol. 6, No. 2.

Stigltz J. E (1989) The economics of rural organization: Theory, practice, and policy. Oxford University Press. Oxford.

Tsegaye Anebo (2005) Performance analysis report for Ethiopian MFIs. AEMFI. Bulletin No.1

Wolday Amha (2002) Product development in the Ethiopian microfinance industry: Challenges and Prospects. AEMFI. Occasional Paper 4.

Wolday Amha (2003) Microfinance in Ethiopia: Performance, challenges and the role in poverty reduction. AEMFI. Occasional Paper No. 7.

Wolday Amha (2005) Prudential regulation of the microfinance industry: Lessons from Ethiopia. AEMFI. Occasional Paper No. 15

Wolday Amha and Gebrehiwot Ageba (2004) Business Development Services (BDS) in Ethiopia: Status, Prospects and Challenges in the Micro and Small Enterprise Sector. A paper presented on the fourth international conference in microfinance development in Ethiopia. Awassa

Yaron J. (1992) Successful rural finance institutions, Discussion Paper No. 150. Washington D.C, World Bank 
Annex 1: Amhara Credit \& Savings Institution

\begin{tabular}{lrr}
\hline \multicolumn{1}{c}{ Indicators } & $\mathbf{2 0 0 4}$ & $\mathbf{2 0 0 3}$ \\
\hline Outreach & 351,163 & 288,681 \\
Number of Active Borrowers & $308,934,727$ & $206,745,388$ \\
Gross Loan Portfolio & $172,797,599$ & $128,649,147$ \\
Savings Balance & & \\
Profitability & $231.8 \%$ & $178.4 \%$ \\
Operational Self-Sufficiency & $156.0 \%$ & $137.0 \%$ \\
Financial Self-Sufficiency & & \\
Efficiency & $6.2 \%$ & $7.6 \%$ \\
Operating Expense/ Loan Portfolio & $4.2 \%$ & $5.3 \%$ \\
Personnel Expense/ Loan Portfolio & & 195 \\
Productivity & 210 & 293 \\
Borrowers per Staff Member & 335 & $1.7 \%$ \\
Borrowers per Loan Officer & & $2.2 \%$ \\
Portfolio Quality & $0.5 \%$ & \\
Portfolio at Risk> 30 Days & $1.5 \%$ & \\
Write-off Ratio & & \\
\hline
\end{tabular}

Annex 2: Addis credit \& savings institution

\begin{tabular}{lrr}
\hline \multicolumn{1}{c}{ Indicators } & $\mathbf{2 0 0 4}$ & $\mathbf{2 0 0 3}$ \\
\hline Outreach & 31,841 & 14,271 \\
Number of Active Borrowers & $41,016,579$ & $8,734,856$ \\
Gross Loan Portfolio & $6,215,161$ & $2,982,394$ \\
Savings Balance & & \\
Profitability & $103.0 \%$ & $84.9 \%$ \\
Operational Self-Sufficiency & $54.0 \%$ & $60.4 \%$ \\
Financial Self-Sufficiency & & \\
Efficiency & $7.9 \%$ & $14.3 \%$ \\
Operating Expense/ Loan Portfolio & $5.2 \%$ & $8.9 \%$ \\
Personnel Expense/ Loan Portfolio & & \\
Productivity & 215 & 274 \\
Borrowers per Staff Member & 388 & \\
Borrowers per Loan Officer & & $7.8 \%$ \\
Portfolio Quality & $20.6 \%$ & $5.9 \%$ \\
\hline Portfolio at Risk> 30 Days & $3.3 \%$ & \\
Write-off Ratio & & \\
\hline
\end{tabular}


Annex 3: Africa village financial services

\begin{tabular}{lrr}
\hline \multicolumn{1}{c}{ Indicators } & \multicolumn{1}{c}{$\mathbf{2 0 0 4}$} & $\mathbf{2 0 0 3}$ \\
\hline Outreach & & \\
Number of Active Borrowers & 4,867 & 2,866 \\
Gross Loan Portfolio & $2,943,430$ & $2,221,793$ \\
Savings Balance & $1,077,809$ & 658,421 \\
Profitability & & \\
Operational Self-Sufficiency & $73.2 \%$ & $91.3 \%$ \\
Financial Self-Sufficiency & $63.1 \%$ & $64.9 \%$ \\
Efficiency & & \\
Operating Expense/ Loan Portfolio & $18.5 \%$ & $21.0 \%$ \\
Personnel Expense/ Loan Portfolio & $12.9 \%$ & $14.8 \%$ \\
Productivity & & 92 \\
Borrowers per Staff Member & 125 & 239 \\
Borrowers per Loan Officer & 304 & $11.6 \%$ \\
Portfolio Quality & & $0.6 \%$ \\
Portfolio at Risk> 30 Days & $2.3 \%$ & \\
Write-off Ratio & $14.3 \%$ & \\
\hline
\end{tabular}

\section{Annex 4: Bussa Gonofa MFI}

\begin{tabular}{lrr}
\hline \multicolumn{1}{c}{ Indicators } & $\mathbf{2 0 0 4}$ & $\mathbf{2 0 0 3}$ \\
\hline Outreach & & \\
Number of Active Borrowers & 5,571 & 5,999 \\
Gross Loan Portfolio & $2,116,415$ & $2,133,046$ \\
Savings Balance & 749,178 & 458,880 \\
Profitability & & \\
Operational Self-Sufficiency & $100.4 \%$ & $104.1 \%$ \\
Financial Self-Sufficiency & $80.2 \%$ & $86.6 \%$ \\
Efficiency & & \\
Operating Expense/ Loan Portfolio & $41.8 \%$ & $40.0 \%$ \\
Personnel Expense/ Loan Portfolio & $21.9 \%$ & $21.6 \%$ \\
Productivity & & 182 \\
Borrowers per Staff Member & 151 & 261 \\
Borrowers per Loan Officer & 232 & $5.8 \%$ \\
Portfolio Quality & & $5.6 \%$ \\
Portfolio at Risk> 30 Days & $3.9 \%$ & \\
Write-off Ratio & $2.1 \%$ & \\
\hline
\end{tabular}


Wolday Amha: Managing growth of microfinance institutions:...

Annex 5: Dedebit Credit \& Savings Institution

\begin{tabular}{lrr}
\hline \multicolumn{1}{c}{ Indicators } & $\mathbf{2 0 0 4}$ & \multicolumn{1}{c}{$\mathbf{2 0 0 3}$} \\
\hline Outreach & 336,733 & 225,996 \\
Number of Active Borrowers & $377,726,250$ & $186,012,798$ \\
Gross Loan Portfolio & $153,776,824$ & $131,346,540$ \\
Savings Balance & & \\
Profitability & $215.5 \%$ & $180.4 \%$ \\
Operational Self-Sufficiency & $125.3 \%$ & $95.7 \%$ \\
Financial Self-Sufficiency & & \\
Efficiency & $3.8 \%$ & $6.1 \%$ \\
Operating Expense/ Loan Portfolio & $2.3 \%$ & $3.7 \%$ \\
Personnel Expense/ Loan Portfolio & & \\
Productivity & 388 & 1,345 \\
Borrowers per Staff Member & 1,840 & $6.2 \%$ \\
Borrowers per Loan Officer & & $12.4 \%$ \\
Portfolio Quality & $2.3 \%$ & \\
Portfolio at Risk> 30 Days & $7.1 \%$ & \\
Write-off Ratio & & \\
\hline
\end{tabular}

Annex 6: Eshet Microfinance Institution

\begin{tabular}{lrr}
\hline \multicolumn{1}{c}{ Indicators } & \multicolumn{1}{c}{$\mathbf{2 0 0 4}$} & $\mathbf{2 0 0 3}$ \\
\hline Outreach & 9,728 & 6,540 \\
Number of Active Borrowers & $7,343,034$ & $3,826,461$ \\
Gross Loan Portfolio & 850,800 & 456,596 \\
Savings Balance & & \\
Profitability & $155.0 \%$ & $103.8 \%$ \\
Operational Self-Sufficiency & $119.7 \%$ & $80.8 \%$ \\
Financial Self-Sufficiency & & $24.7 \%$ \\
Efficiency & $14.7 \%$ & $14.3 \%$ \\
Operating Expense/ Loan Portfolio & $8.6 \%$ & 152 \\
Personnel Expense/ Loan Portfolio & & 226 \\
Productivity & 191 & \\
Borrowers per Staff Member & 278 & $0.1 \%$ \\
Borrowers per Loan Officer & & $0.1 \%$ \\
Portfolio Quality & $0.9 \%$ & \\
Portfolio at Risk> 30 Days & $0.0 \%$ & \\
Write-off Ratio & & \\
\hline
\end{tabular}


Annex 7: Gasha Microfinance institution

\begin{tabular}{lrr}
\hline \multicolumn{1}{c}{ Indicators } & $\mathbf{2 0 0 4}$ & $\mathbf{2 0 0 3}$ \\
\hline Outreach & & \\
Number of Active Borrowers & 8,121 & 6,423 \\
Gross Loan Portfolio & $5,772,922$ & $2,751,235$ \\
Savings Balance & $3,212,941$ & $2,110,068$ \\
Profitability & & \\
Operational Self-Sufficiency & $72.5 \%$ & $60.8 \%$ \\
Financial Self-Sufficiency & $45.2 \%$ & $40.6 \%$ \\
Efficiency & & \\
Operating Expense/ Loan Portfolio & $25.0 \%$ & $42.5 \%$ \\
Personnel Expense/ Loan Portfolio & $15.7 \%$ & $27.9 \%$ \\
Productivity & & \\
Borrowers per Staff Member & 110 & 169 \\
Borrowers per Loan Officer & 214 & $18.6 \%$ \\
Portfolio Quality & & $25.2 \%$ \\
Portfolio at Risk> 30 Days & $4.6 \%$ & \\
Write-off Ratio & $18.9 \%$ & \\
\hline
\end{tabular}

Annex 8: Meklit Microfinance Institution

\begin{tabular}{lrr}
\hline \multicolumn{1}{c}{ Indicators } & $\mathbf{2 0 0 4}$ & $\mathbf{2 0 0 3}$ \\
\hline Outreach & 3,939 & 3,577 \\
Number of Active Borrowers & $2,550,718$ & $1,839,088$ \\
Gross Loan Portfolio & $1,886,385$ & $1,332,872$ \\
Savings Balance & & \\
Profitability & $110.3 \%$ & $88.7 \%$ \\
Operational Self-Sufficiency & $69.3 \%$ & $76.3 \%$ \\
Financial Self-Sufficiency & & \\
Efficiency & $15.3 \%$ & $14.2 \%$ \\
Operating Expense/ Loan Portfolio & $8.6 \%$ & $8.8 \%$ \\
Personnel Expense/ Loan Portfolio & & 163 \\
Productivity & 146 & 397 \\
Borrowers per Staff Member & 328 & \\
Borrowers per Loan Officer & & $9.7 \%$ \\
Portfolio Quality & $17.7 \%$ & $12.5 \%$ \\
Portfolio at Risk> 30 Days & $14.8 \%$ & \\
Write-off Ratio & & \\
\hline
\end{tabular}


Wolday Amha: Managing growth of microfinance institutions:...

Annex 9: OMO Microfinance Institution

\begin{tabular}{lrr}
\hline \multicolumn{1}{c}{ Indicators } & \multicolumn{1}{c}{$\mathbf{2 0 0 4}$} & $\mathbf{2 0 0 3}$ \\
\hline Outreach & 75,439 & 70,590 \\
Number of Active Borrowers & $30,807,793$ & $23,940,625$ \\
Gross Loan Portfolio & $25,969,672$ & $20,882,518$ \\
Savings Balance & & \\
Profitability & $106.4 \%$ & $88.7 \%$ \\
Operational Self-Sufficiency & $62.5 \%$ & $49.1 \%$ \\
Financial Self-Sufficiency & & \\
Efficiency & $16.4 \%$ & $14.0 \%$ \\
Operating Expense/ Loan Portfolio & $9.6 \%$ & $8.2 \%$ \\
Personnel Expense/ Loan Portfolio & & \\
Productivity & 211 & 209 \\
Borrowers per Staff Member & 254 & 252 \\
Borrowers per Loan Officer & & $11.4 \%$ \\
Portfolio Quality & $5.5 \%$ & $26.3 \%$ \\
Portfolio at Risk> 30 Days & $26.0 \%$ & \\
Write-off Ratio & & \\
\hline
\end{tabular}

Annex 10: Oromia Credit \& Savings s.c

\begin{tabular}{lrr}
\multicolumn{1}{c}{ Indicators } & \multicolumn{1}{c}{$\mathbf{2 0 0 4}$} & \multicolumn{2}{c}{$\mathbf{2 0 0 3}$} \\
\hline Outreach & & \\
Number of Active Borrowers & 86,998 & 62,150 \\
Gross Loan Portfolio & $87,981,405$ & $63,397,462$ \\
Savings Balance & $28,477,428$ & $19,469,477$ \\
Profitability & & \\
Operational Self-Sufficiency & $152.3 \%$ & $94.9 \%$ \\
Financial Self-Sufficiency & $94.8 \%$ & $64.4 \%$ \\
Efficiency & & $10.8 \%$ \\
Operating Expense/ Loan Portfolio & $9.0 \%$ & $6.2 \%$ \\
Personnel Expense/ Loan Portfolio & $5.4 \%$ & 133 \\
Productivity & & 256 \\
Borrowers per Staff Member & 185 & \\
Borrowers per Loan Officer & 1,208 & $7.8 \%$ \\
Portfolio Quality & & $0.0 \%$ \\
Portfolio at Risk> 30 Days & $5.0 \%$ & \\
Write-off Ratio & $0.0 \%$ & \\
\hline
\end{tabular}


Annex 11: Poverty Eradication \& Community Empowerment

\begin{tabular}{lrr}
\hline \multicolumn{1}{c}{ Indicators } & $\mathbf{2 0 0 4}$ & $\mathbf{2 0 0 3}$ \\
\hline Outreach & 7,766 & 5,428 \\
Number of Active Borrowers & $7,696,972$ & $5,192,843$ \\
Gross Loan Portfolio & $1,921,456$ & $1,185,314$ \\
Savings Balance & & \\
Profitability & $152.5 \%$ & $80.4 \%$ \\
Operational Self-Sufficiency & $120.2 \%$ & $67.4 \%$ \\
Financial Self-Sufficiency & & \\
Efficiency & $17.5 \%$ & $20.6 \%$ \\
Operating Expense/ Loan Portfolio & $8.4 \%$ & $9.6 \%$ \\
Personnel Expense/ Loan Portfolio & & \\
Productivity & 127 & 118 \\
Borrowers per Staff Member & 518 & 603 \\
Borrowers per Loan Officer & & \\
Portfolio Quality & $0.1 \%$ & $0.0 \%$ \\
Portfolio at Risk> 30 Days & $0.0 \%$ & \\
Write-off Ratio & & \\
\hline
\end{tabular}

Annex 12: Sidama Microfinance Institution

\begin{tabular}{lrr}
\hline \multicolumn{1}{c}{ Indicators } & $\mathbf{2 0 0 4}$ & $\mathbf{2 0 0 3}$ \\
\hline Outreach & & \\
Number of Active Borrowers & 9,891 & 11,346 \\
Gross Loan Portfolio & $9,216,374$ & $8,375,810$ \\
Savings Balance & $2,906,440$ & $2,448,583$ \\
Profitability & & \\
Operational Self-Sufficiency & $83.1 \%$ & $57.2 \%$ \\
Financial Self-Sufficiency & $50.8 \%$ & $36.6 \%$ \\
Efficiency & & $19.2 \%$ \\
Operating Expense/ Loan Portfolio & $16.4 \%$ & $10.2 \%$ \\
Personnel Expense/ Loan Portfolio & $8.6 \%$ & \\
Productivity & & 298 \\
Borrowers per Staff Member & 89 & $29.2 \%$ \\
Borrowers per Loan Officer & 267 & $0.0 \%$ \\
Portfolio Quality & & \\
Portfolio at Risk> 30 Days & $26.2 \%$ & \\
Write-off Ratio & $0.0 \%$ & \\
\hline
\end{tabular}


Wolday Amha: Managing growth of microfinance institutions:...

Annex 13: Specialized Financial \& Promotional Institution

\begin{tabular}{lrr}
\hline \multicolumn{1}{c}{ Indicators } & $\mathbf{2 0 0 4}$ & $\mathbf{2 0 0 3}$ \\
\hline Outreach & 11,430 & 9,552 \\
Number of Active Borrowers & $9,900,830$ & $7,384,358$ \\
Gross Loan Portfolio & $4,284,237$ & $3,868,522$ \\
Savings Balance & & \\
Profitability & $103.7 \%$ & $106.1 \%$ \\
Operational Self-Sufficiency & $80.6 \%$ & $79.3 \%$ \\
Financial Self-Sufficiency & & \\
Efficiency & $15.8 \%$ & $18.5 \%$ \\
Operating Expense/ Loan Portfolio & $9.2 \%$ & $10.1 \%$ \\
Personnel Expense/ Loan Portfolio & & \\
Productivity & 176 & 180 \\
Borrowers per Staff Member & 408 & 415 \\
Borrowers per Loan Officer & & \\
Portfolio Quality & $1.5 \%$ & $1.5 \%$ \\
Portfolio at Risk> 30 Days & $3.9 \%$ & \\
Write-off Ratio & & \\
\hline
\end{tabular}

Annex 14: Wasasa Microfinance Institution

\begin{tabular}{lrr}
\hline \multicolumn{1}{c}{ Indicators } & $\mathbf{2 0 0 4}$ & $\mathbf{2 0 0 3}$ \\
\hline Outreach & 8,949 & 3,728 \\
Number of Active Borrowers & $5,331,693$ & $2,250,997$ \\
Gross Loan Portfolio & $1,475,239$ & 577,488 \\
Savings Balance & & \\
Profitability & $145.2 \%$ & $139.9 \%$ \\
Operational Self-Sufficiency & $118.4 \%$ & $107.7 \%$ \\
Financial Self-Sufficiency & & \\
Efficiency & $17.9 \%$ & $16.9 \%$ \\
Operating Expense/ Loan Portfolio & $11.3 \%$ & $10.3 \%$ \\
Personnel Expense/ Loan Portfolio & & \\
Productivity & 160 & 129 \\
Borrowers per Staff Member & 344 & 266 \\
Borrowers per Loan Officer & & \\
Portfolio Quality & & $5.9 \%$ \\
Portfolio at Risk> 30 Days & $0.1 \%$ & $1.2 \%$ \\
Write-off Ratio & $4.5 \%$ & \\
\hline
\end{tabular}


Annex 15: Wisdom Microfinance Institution

\begin{tabular}{lrr}
\hline \multicolumn{1}{c}{ Indicators } & \multicolumn{1}{c}{$\mathbf{2 0 0 4}$} & $\mathbf{2 0 0 3}$ \\
\hline Outreach & 19,912 & 12,151 \\
Number of Active Borrowers & $18,710,578$ & $11,626,351$ \\
Gross Loan Portfolio & $5,633,654$ & $4,043,453$ \\
Savings Balance & & \\
Profitability & $115.5 \%$ & $88.6 \%$ \\
Operational Self-Sufficiency & $88.0 \%$ & $78.8 \%$ \\
Financial Self-Sufficiency & & $20.8 \%$ \\
Efficiency & $19.9 \%$ & $8.8 \%$ \\
Operating Expense/ Loan Portfolio & $9.9 \%$ & 120 \\
Personnel Expense/ Loan Portfolio & & 320 \\
Productivity & 133 & \\
Borrowers per Staff Member & 262 & $5.3 \%$ \\
Borrowers per Loan Officer & & $6.9 \%$ \\
Portfolio Quality & $3.5 \%$ & \\
Portfolio at Risk> 30 Days & $5.6 \%$ & \\
Write-off Ratio & & \\
\hline
\end{tabular}

